\title{
Maruta Pranka
}

\section{BIOGRĀFISKĀ PIEEJA BIOGRĀFISKĀ PĀRRĀVUMA INDIVIDUĀLO UN SOCIĀLO ASPEKTU ANALİZĒ}

Promocijas darba kopsavilkums socioloǵijas doktora zinātniskā grāda iegūšanai

Specialitāte - socioloğija

Rīga, 2015 


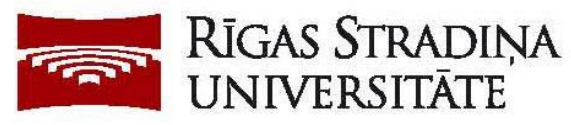

Maruta Pranka

\title{
BIOGRĀFISKĀ PIEEJA BIOGRĀFISKĀ PĀRRĀVUMA INDIVIDUĀLO UN SOCIĀLO ASPEKTU ANALİZĒ
}

\author{
Promocijas darba kopsavilkums \\ Sociologiijas doktora zinātniskā grāda iegūšanai
}

Specialitāte - sociologiija

Rīga, 2014. gads 
Promocijas darbs izstrādāts: Rīgas Stradiṇa universitātē

Darba zinātniskā vadītāja:

Dr. sc. soc., asociētā profesore Ritma Rungule,

Rīgas Stradiṇa universitāte

Darba zinātniskais konsultants:

Dr. biol., profesors Edvīns Miklaševičs,

Rīgas Stradiņa universitāte

Oficiālie recenzenti:

Dr.sc.soc. docente Agita Lūse,

Rīgas Stradiņa Universitāte

Dr.sc.soc. asociētā profesore Baiba Bela,

Latvijas Universitāte

Dr. med. asociētā profesore Anita Villeruša,

Rīgas Stradiņa universitāte

Promocijas darba aizstāvēšana notiks: 2015. gada 31. martā plkst.10.00 Rīgas Stradiṇa universitātes Socioloğijas Promocijas padomes atklātā sēdē Rīgā, Dzirciema ielā 16, Hipokrāta auditorijā.

Ar promocijas darbu var iepazīties RSU bibliotēkā un RSU mājaslapā: www.rsu.lv

Promocijas darbs veikts ar Eiropas sociālā fonda projekta

“Atbalsts doktorantiem studiju programmas apguvei un zinātniskā grāda ieguvei Rīgas Stradiṇa universitātē” finansiālu atbalstu
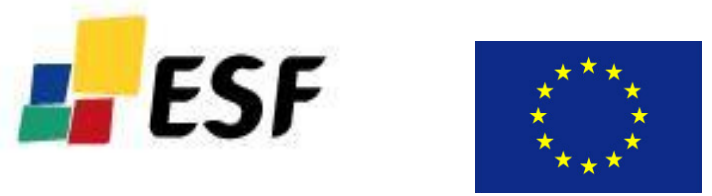

Promocijas padomes sekretārs:

Dr.phil. soc.d. docente Signe Dobelniece, Rīgas Stradiņa Universitāte 


\section{SATURS}

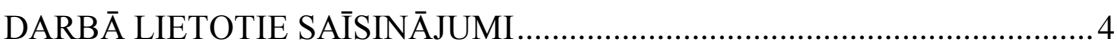

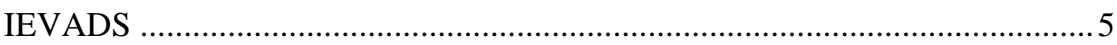

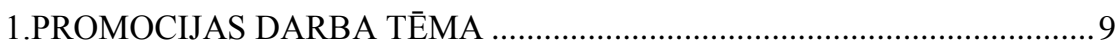

1.1. Pētnieciskās tēmas zinātniskā novitāte un aktualitāte ......................... 9

1.2. Promocijas darba mērķis un uzdevumi ...................................... 11

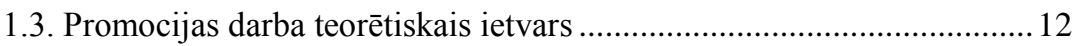

1.4. Empīriskās analīzes metodoloğija un datu avoti ............................... 17

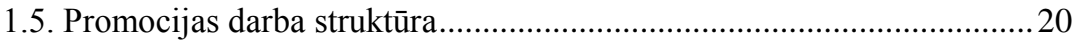

2. GALVENIE REZULTĀTI UN SECINĀJUMI ...................................... 23

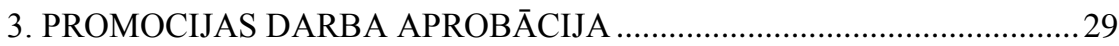

3.1. Promocijas darba autores zinātniskās publikācijas par promocijas darba tēmu 29

3.2. Referāti un ziņojumi par promocijas darba tēmu konferencēs un

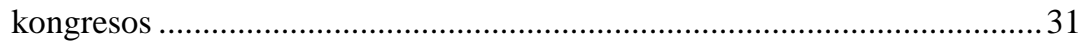

3.3. Publicētās tēzes zinātnisko konferenču tēžu krājumos un interneta

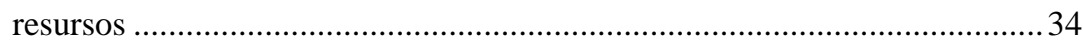

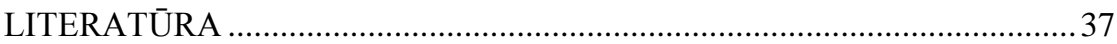




\section{DARBĀ LIETOTIE SAĪSINĀJUMI}

Brc - krūts vēzis

Dzkv - dzemdes kakla vēzis

FSI - Filozofijas un sociologijas institūts

LU - Latvijas Universitāte

Ov - olnīcu vēzis

RSU - Rīgas Stradiṇa universitāte

(54) - iekavās norādīts respondenta vecums

V - vesela 


\section{IEVADS}

Sociologijā interesi par indivīda dzīves gājumu nosaka viens no socioloğijas pētnieciskajiem uzdevumiem - izzināt aspektus, faktorus, elementus, kas veido un ietekmē indivīda sociālo būtību. Socioloǵijā dzīves gājuma pētījumos uzmanība tiek pievērsta gan attiecībām starp sociālajām pārmain̄ām un biogrāfiju, gan tam, kā notiek biogrāfijas piemērošanās main̄̄gajai kultūras un sociālajai videi mainīgajā laikā, gan arī racionālās izvēles nozīmei kā izšķirošam faktoram sociālās pozicionēšanās dinamikā (Heinz \& Krüger 2001).

Biogrāfija ir stāsts par indivīda dzīves gājumu jeb dzīvesstāsts, kas ietver ne vien indivīda sociāldemogrāfisko raksturojumu un dzīves faktus, - tā atspogulo arī indivīda subjektīvo pieredzi un faktu un notikumu interpretāciju.

Biogrāfiskā pārrāvuma jēdziens raksturo tādu būtisku, pēkšņu notikumu ietekmi uz indivīda dzīves gājumu, kas kardināli maina tā virzību un ieceres. Būtiskas pārmaiņas, kas skar indivīdu, tiek piedzīvotas gan objektīvi, gan iegūst savu subjektīvo skaidrojumu un interpretāciju indivīda biogrāfijā.

Terminu biogrāfiskais pārrāvums 1982. gadā ieviesa britu sociologs Maiks Berijs (Bury), aprakstot hroniskas slimības pieredzi un raksturojot veidu, kādā dzīvībai bīstama slimība lauž indivīda sociālo un kultūras pieredzi, pakḷaujot vinuu pašidentitātes apdraudējumam. Analizējot slimības kā biogrāfiskā pārrāvuma pieredzi, Berijs izmantoja Entonija Gidensa jēdzienu kritiskā situācija (critical situation), ko Gidenss attiecināja uz sociāla rakstura pārrāvumiem, pieņemot, ka būtiskiem notikumiem biogrāfijā ir tāda pati ietekme (Giddens 1979).

Promocijas darbā jēedziens biogrāfiskais pārrāvums tiek interpretēts kā process, kas ietver būtiskas pārmaiņas indivīda dzīves gājumā un biogrāfijā kā dzīves gājuma uztverē un interpretācijā. Biogrāfiskais pārrāvums tiek analizēts 
kā process, ko izraisa pagrieziena punkts (Strauss 1959) vai liktenīgais moments (Giddens 1991), kas ir pamatā indivīda identitātes turpmākām pārmain̄ām. Berijs ir aplūkojis hroniskas slimības ietekmi uz būtiskām biogrāfijas un identitātes pārmaiņām un secinājis, ka hroniska slimība ietekmē indivīda biogrāfiju šādos veidos:

1) mainās paradumi un dzīves uztvere;

2) mainās attiecības starp slimo indivīdu un personām viņa sociālajā tīklojumā; dažas no attiecībām var tikt zaudētas, citas - mainīties;

3) ir nepieciešama resursu - laika, enerğijas, finanšu, giimenes, draugu mobilizācija (Bury 1982: 169).

Promocijas darba autore izmanto E. Gidensa formulēto liktenīgo momentu konceptu, lai paplašinātu biogrāfiskā pārrāvuma jēdziena saturu, uzsverot mainītajai situācijai atbilstošu indivīda iespēju aspektus liktenīgajos momentos, kad indivīdam, iesaistot ekspertu sistēmu (dažādas institūcijas, dz̄ives stila diskursa maiņas utt.) var tikt dotas iespējas. Promocijas darbā analizēta ekspertu iesaistīšanas nozīme, uzsvērti nepieciešamās kvalitātes aspekti.

Liktenīgie momenti izraisa procesu, kad indivīds var kḷūt par pilnīgi citu personu. Likten̄̄gie momenti var potenciāli dot pieredzes iespējas, kā arī attīstīt pašidentitāti un nākotnes rīcības. Tādējādi "izšķirošie lēmumi, kas tiek pieņemti, turpmāk pārveido identitātes refleksīvo projektu, kas atbilstīgi maina dzīves stilu" (Giddens 1991: 143).

Promocijas darba centrālais jēdziens biogrāfiskais pārrāvums analizēts kā atšķirīgu cēloṇu izraisīts. Viens no cēloṇiem ir smagas hroniskas slimības krūts vēža vai olnīcu vēža - paaugstināts risks, ko indivīds saṇem ǵenētiskā mantojuma cel̦ā, būdams ar asinsradniecības saitēm saistîts noteiktas ǵimenes loceklis. Otrs šajā darbā analizētais biogrāfisko pārrāvumu cēlonis ir kardinālas sociālās pārmaiņas vēsturisko notikumu - padomju okupācijas un Otrā pasaules kara - kontekstā. 
Biogrāfiskā pārrāvuma individuālie un sociālie aspekti sociologiiski analizēti mijiedarbībā, ņemot vērā, ka katrs indivīds dzīvo noteiktā sociālajā laikā un sociālajā telpā, būdams noteiktas sociālās grupas vai sociālā slāņa pārstāvis, noteiktu sociālo attiecību dalībnieks. Biogrāfiskā pārrāvuma individuālie aspekti ir saistīti ar ikviena indivīda unikālo būtību un pieredzi, dzīves gājuma interpretāciju. Biogrāfiskā pārrāvuma procesāa, ko ievada kritiskās situācijas vai liktenīgie momenti, kā arī tā pārvarēšanā nozīme ir individuālajai pieredzei, indivīda raksturam, uztveres īpatnībām, temperamentam, dažādiem identitātes aspektiem. Sociālie aspekti attiecas uz indivīda dzīves gājumu sociālajā vidē - noteiktā laikā un telpā, noteiktā kolektīvā un sociālajās attiecībās, biogrāfijā ietverot notikumu, pārmainuu pieredzes interpretāciju. Indivīds, būdams vēsturisks un sociāls ağents, akumulē savas sociālās grupas, sociālās vides pieredzi, kas pārklājas/mijiedarbojas ar individuālo pieredzi. Sociālo mijattiecību ietvaros individuālā pieredze tiek komunicēta citiem sabiedrības locekḷiem valodas formā, kas ir sociāls veidojums. Biogrāfiskā pārāvuma individuālie un sociālie aspekti atrodas nepārtrauktā mijiedarbībā un nav savstarpēji nošķirami. Tas nozīmē, ka biogrāfiskais pārrāvums var tikt vispusīgi un dziļi izprasts, analizējot indivīda biogrāfiju visa viṇa dzīves gājuma laikā, kura ietvaros nepārtraukti aktualizējas saistība starp sociālo vidi un indivīdu.

Biogrāfiskā pārrāvuma jēdziens raksturo procesu, kurā būtiski, pēkšņi notikumi ietekmē indivīda dzīves gājumu, kardināli maina tā virzību, indivīda plānus un ieceres. Šīs būtiskās pārmaiṇas tiek piedzīvotas objektīvi, kā arī tās iegūst savu subjektīvo skaidrojumu un interpretāciju indivīda biogrāfijā.

Promocijas darbs izstrādāts, balstoties uz empīrisko pētījumu, kas ietver divas daļas. Smagas hroniskas slimības vai tās paaugstināta riska kā biogrāfiskāa pārrāvuma izpētē promocijas darbā izmantoti empīriskā pētījuma dati, ko darba autore ieguvusi, strādājot Rīgas Stradiņa universitātes Onkolog̣ijas institūta veiktā starpdisciplinārā pētījuma projektā "Jaunas starpdisciplināras zinātniskās 
grupas izveide krūts vēža izpētei, terapijas efektivitātes un pacienta dzīves kvalitātes uzlabošanai" (vienošanās $\mathrm{Nr}$. 2009/0230/1DP/1.1.1.2.0/09/APIA/VIAA/070).

Kardinālu sociālo pārmainuu izraisīta biogrāfiskā pārrāvuma izpētē izmantoti empīriskie dati no longitudināla pētījuma, kas veikts Latvijas Universitātes Filozofijas un sociologijas institūta Nacionālās mutvārdu vēstures projektā. Kopš 1996. gada vairāku gadu garumā, izmantojot biogrāfisko pieeju, veikts pētījums Māja, kurā par informācijas avotu izmantotas dzīvesstāstu intervijas, kā arī ar stāstîtāju aț̣auju pieejamie personiskie dokumenti. 


\section{PROMOCIJAS DARBA TËMA}

\subsection{Pētnieciskās tēmas zinātniskā novitāte un aktualitāte}

Pētnieciskās tēmas darba novitāte

1. Promocijas darbs ir Latvijā pirmais, kurā sociologiski analizēts biogrāfiskā pārrāvuma process, tā individuālie un sociālie aspekti. Promocijas darbā analizētos biogrāfiskos pārrāvumus izraisa dažādi cēloṇi, un tas nosaka tā atšķirīgās izpausmes, tomēr pētījuma analīzes procesā ir identificētas kopīgas būtiskās pazīmes. Promocijas darba autore M. Berija definētajām trīs pazīmēm - identitātes transformācija, mainītas sociālās attiecības, ekspertu iesaistes nepieciešamība - kā novitāti atzīmē un pievieno pazīmi - pārmaingas indivīda rīcībā esošo kapitālu un resursu pieejamībā un izmantošanā. Lai gan biogrāfiskā pārrāvuma situācijā indivīdam palielinās nepieciešamība pēc dažādiem resursiem, pieeja tiem, kā arī savu kapitālu izmantošana ir samazināta vai pat kḷūst neiespējama.

Līdzās identificētajām kopīgajām raksturīgajām pazīmēm jāuzsver arī tas promocijas darbā analizēto biogrāfisko pārrāvumu aspekts, ka šo pārrāvumu rašanos ietekmējusi indivīdu piederība noteiktai ǵimenei - slimības vai tās paaugstinātas iespējamības gadījuma tā ir gimene, kurā no paaudzes paaudzē tiek nodoti pārmantotā krūts vēža gēni. Arī sociālo pārmaiņu izraisīta biogrāfiskā pārrāvuma gadījumā tā ir gimenes piederība noteiktam sociālajam slānim - turīgajai vidusšķirai, pret kuru noteiktā vēsturiskajā un sociālajā laikā un telpā vērstas represijas.

2. Promocijas darba novitāte saistās ar to, ka Latvijā līdz šim nav pētīti ǵenētiskā mantojuma izraisīta paaugstināta slimības riska un slimības kā ǵenētiskā mantojuma socioloǵiskie aspekti. Latvijā ir veikti pētījumi veselības un slimību sociologijāa un antropologijāa Tomēr promocijas darbs ir pirmais 
pētījums, kas Latvijā veikts par biogrāfisko pārrāvumu, kam pamatā ir paaugstināta slimības iespēja, ko izraisījis ǵenētiskais mantojums. Promocijas darba ietvaros veiktais un analizētais empīriskais pētījums papildina slimības kā biogrāfiskā pārrāvuma konceptu ar atziņu, ka biogrāfiskais pārrāvums un tajā ietvertās identitātes pārmaiņas attiecas arī uz situāciju, kad biogrāfisko pārrāvumu ietekmē ǵenētiskais mantojums, šajā gadījumā paaugstināts risks saslimt ar krūts vai/un olnīcu vēzi.

3. Viens no būtiskākajiem novitātes aspektiem ir jaunievedumi pētījuma metodologijāa Promocijas darbā pētītie biogrāfiskie pārrāvumi, ko izraisījuši dažādi cēloṇi, analizēti ar vienotu metodologisko - biogrāfisko - pieeju, identificējot kopīgās un atšķiirīgās procesu pazīmes. Tas veido metodoloǵisko pamatu turpmākiem sociologiiskiem pētījumiem par biogrāfiskā pārrāvuma procesu, tā individuālajiem un sociālajiem aspektiem, kā arī par tā pārvarēšanas iespējām, kas var ietekmēt kā individuālo, tā visas sabiedrības labklājību.

4. Metodologískā aspektā jāuzsver vēl kāds jauninājums: sociālo pārmaiņu izraisīta biogrāfiskāa pārrāvuma izpēte veikta kā ilglaicīgs jeb longitudināls gadījuma pētījums, izzinot kardinālu sociālo pārmaiṇu izraisīta biogrāfiskā pārrāvuma procesus. Šāda veida pētījums, lietojot biogrāfisko pieeju un dzīvesstāstus kā metodi, līdz šim Latvijā nav veikts. Biogrāfiskāā pieeja, veicot ilglaicīgo gadījuma pêtījumu, fiksē indivīdu personiskās pieredzes saistībā ar kardinālām sociālajām transformācijām.

\section{Pētnieciskās tēmas aktualitāte}

Vēsturiskā pieredze ar kardinālām sociālajām transformācijām un tagadnes dinamiskās pārmaiṇas sociālās telpas visās sistēmās rada biogrāfiskā pārrāvuma riskus indivīdu biogrāfijās. Biogrāfisko pārrāvumu var izraisīt arī personiska rakstura kritiskas situācijas indivīdu dzīves gājumā, rosinot indivīdu un veselu sabiedrības grupu stigmatizācijas riskus. Dažāda veida cēloṇu izraisītu biogrāfiskā pārrāvuma procesu izziņa, kā arī to pārvarēšanas veidu un 
iespēju identificēšana, var kḷūt par pamatu, lai palīdzētu indivīdiem pārvarēt biogrāfisko pārrāvumu un veicinātu vinuu individuālo un sociālo labklājīibu.

Pētījuma aktualitāti nosaka arī tas, ka, pieaugot jaunām diagnosticēšanas iespējām un tehnologiju attīstībai veselības aprūpē, indivīds tiek analizēts detaļās un detalizēti, bieži vien nepievēršot pietiekamu uzmanību indivīda identitātes aspektiem un dzīves gājuma pieredzes saistībai ar veselības problēmām. Sociologiski izzinot biogrāfiskā pārrāvuma procesu, kura rašanos ietekmē pārmantotais vēža gēns, iespējama biomedicīnisko un sociālo zinātņu tuvināšanās, lai palīdzētu indivīdiem, pārvarēt veselības problēmu raisītus pārrāvumus dzīves gājumā, identificētu nepieciešamos sociālā atbalsta veidus.

\subsection{Promocijas darba mērķis un uzdevumi}

Promocijas darba mērḳis ir veikt individuālo un sociālo aspektu socioloǵisku izpēti dažādu cēloṇu izraisīta biogrāfiskā pārrāvuma pieredzē, lai noskaidrotu, kādi individuālie un sociālie faktori veicina veiksmīgu biogrāfiskā pārrāvuma pārvarēšanu.

\section{Mērḳa sasniegšanai izvirzītie uzdevumi}

1. Veikt biogrāfiskā pārrāvuma jēdziena teorētisku analīzi, pamatojoties uz līdz šim veiktajiem pētījumiem sociolog̣ijā.

2. Izpētīt biogrāfiskā pārrāvuma pazīmes, analizējot teorētiskos avotus un empīiskā pētījuma datus.

3. Analizēt biogrāfiskās pieejas iespējas un atbilstību biogrāfiskā pārrāvuma individuālo un sociālo aspektu sociolog̣iskā izpētē.

4. Analizēt biogrāfiskā pārrāvuma sociālos un individuālos aspektus, kāa metodologiju izmantojot biogrāfisko pieeju.

5. Izpētīt biogrāfisko pārrāvumu, ko izraisa slimība vai paaugstināts saslimšanas risks, analizējot datus, kas iegūti promocijas darbā veiktajos empīriskajos pētījumos. 
6. Izpētīt biogrāfisko pārrāvumu, ko izraisa kardinālas sociālās pārmaiņas, kuras identificētas, analizējot promocijas darbā veikto empīisko pêtījumu datus.

7. Analizēt tos individuālos un sociālos faktorus, kas indivīdiem rada labvēlīgu situāciju, veicina veiksmīgu biogrāfiskā pārrāvuma pārvarēšanu un ir identificēti, pamatojoties uz promocijas darbā veikto teorētisko un empīrisko datu analīzi.

Pētījuma objekts ir individuālu un sociālu cēloṇu izraisīts biogrāfiskais pārrāvums indivīdu dzīves gājumā.

Pētījuma priekšmets ir kardinālu sociālo pārmaiņu un paaugstināta slimības riska izraisīta biogrāfiskā pārrāvuma pieredzes individuālie un sociālie aspekti.

Promocijas darbā izvirzītie pētnieciskie jautājumi

1. Kādi sociālie un individuālie aspekti raksturīgi biogrāfiskā pārrāvuma procesam?

2. Kādas ir dažādu cēloṇu izraisītu biogrāfisko pārrāvumu būtiskākās pazīmes?

3. Kādi individuālie un sociālie faktori rada indivīdiem labvēlīgu situāciju un veicina veiksmīgu biogrāfiskā pārrāvuma pārvarēšanu?

\subsection{Promocijas darba teorētiskais ietvars}

Biogrāfiskais pārrāvums promocijas darbā tiek analizēts kā kardinālu pārmaiṇu izraisīts notikums indivīda dz̄ives gājumā, biogrāfiju apskatot kā dz̄ives gājuma subjektīvu atspoguļojumu un interpretāciju. Biogrāfija, no vienas puses, attiecas uz sociālo realitāti, kas ietekmē indivīda dzīves gājumu. No otras puses, tā attiecas uz tiem procesiem un notikumiem, ko indivīds vēlas un spēj pastāstīt, t.i., uz viṇa subjektīvo pieredzi un pārdzīvojumiem. 
Lai analizētu biogrāfiskā pārrāvuma individuālos un sociālos aspektus, promocijas darbā tiek izmantota biogrāfiskā pieeja, jo individuālā biogrāfija ir sabiedrības attīstības, sociālo pārmaiņu un procesu, valdošo likumsakarību un individuālās pieredzes mijiedarbības subjektīvs atspoguļojums. Indivīda pieredze dzīves gājumā veidojas gan no attiecībām tuvākajā apkārtējā mikrovidē, gan no attiecībām, kas veidojas makrovidē, t.i., indivīda vietas, lomas dažādās sabiedrības struktūrās, kam indivīda dzīvē ir dažāds nozīmības līmenis.

Analizējot biogrāfisko pārrāvumu, promocijas darbā veikta atsauce uz dzīves gājuma sociolog̣iskajā izpētē izmantoto dzīves trajektorijas jēdzienu, kas ir galvenais koncepts biogrāfijas teorijā, ko attīstīja Frics Šuce (Schütze), pamatojoties uz Anzelma Strosa (Strauss) "temporāli sakārtoto sociālo un subjektīvo procesu savstarpējo saplūšanu" (Schütze 1981).

Biogrāfisko pārrāvumu kā procesu, ko izraisa pagrieziena punkts analizējis Anzelms Stross (Strauss 1959), uzsverot, ka pārmaiṇu procesu vienmēr izraisa kāds viens punkts, proti, pagrieziena punkts. Šis pagrieziena punkts tiek sākotnēji identificēts kā kritiskais notikums, kas provocē personu atzīt, ka "es neesmu tas pats, kas es biju, kas es biju pieradis būt", un to pavada pārsteigums, šoks, sarūgtinājums, apmulsums, spriedzes, sagrāves savas patības pieredzē (Strauss 1959: 95). Atbilstoši šai situācijai indivīds meklē jaunu patību, "lai jauno pieredzi piepildītu ar nozīmi un pārvarētu pārrāvumu, ko izraisījis šis pagrieziena punkts, kas novedis pie identitātes transformācijas" (Boldt 2012: 99).

Terminu biogrāfiskais pārrāuvums ieviesa britu sociologs Maiks Berijs 1982. gadā, aprakstot hroniskas slimības pieredzi un raksturojot veidu, kādā dzīvību apdraudoša slimība lauž indivīda sociālo un kultūras pieredzi, pakḷaujot viṇu pašidentitātes apdraudējumam. Analizējot slimības kā biogrāfiskāa pārrāvuma pieredzi, Berijs izmantoja Gidensa jēdzienu kritiskā situācija (critical situation) (Giddens 1979), ko Gidenss attiecināja uz sociāla rakstura 
pārrāvumiem, pieņemot, ka būtiskiem notikumiem biogrāfijā ir tāda pati ietekme.

Promocijas darbā teorētiskajā analīzē izmantoti Gidensa lietotie termini kritiskā situācija, raksturojot notikumus, kas indivīdu vai grupu dzīvē ievieš būtiskas pārmaiņas liktenīgie momenti (fateful moments), "kad indivīdiem ir jāpieņem lēmumi, kas ir izşķiroši viņu mērķiem, pat vēl vairāk, vinu dzìvei nākotnē, tie ir izšķiroši cilvēka likten̄̄. Liktenīgie momenti ir laiks, kad notikumi veidojas, noliekot indivīdu viņa eksistences krustcelēs. Liktenīgie momenti ir gan kolektīvajā vēsturē, gan indivīdu dzīvēs. Tie ir periodi kad pieņemtā lietu kārtība pēkšņi tiek mainīta dažu būtisku notikumu rezultātā" (Giddens, 1991, 112-113). Gidensam liktenīgo momentu galvenais elements ir tas, ka indivīds apsver noteiktu izvēlu un darbību sekas, un tādejādi iesaistās riska novērtēšanā. Likten̄̄gie momenti var potenciāli dot pieredzes iespējas, kā ar sekām attīstīt pašidentitāti un nākotnes rīcības. Tādejādi "izšķirošie lēmumi, kas tiek pieņemti, turpmāk pārveido identitātes refleksīvo projektu, kas sekojoši izmaina dzīves stilu" (Giddens, 1991, 143).

Promocijas darbā izmantojot Gidensa formulēto liktenīgo momentu konceptu, tiek paplašināts biogrāfiskā pārrāvuma jēdziena saturs, uzsverot mainītajai situācijai atbilstošu indivīda iespēju aspektus liktenīgajos momentos, kad indivīdam var tikt dotas iespējas caur ekspertu sistēmas iesaistǐšanu (dažādas institūcijas, dzīves stila diskursa maiņas utt.). Promocijas darbā analizēta ekspertu iesaistīšanas nozīme, uzsverot ekspertu kvalitātes aspektus.

Promocijas darba autore līdzās biogrāfiskā pārrāvuma jēdzienam analizē citu autoru izstrādātos konceptus par būtisku, pēkšņu notikumu ietekmi un sekām uz individuālajām biogrāfijām, raksturojot procesu līdzīgās izpausmes, tomēr ietverot arī atškirīgu saturu un nozīmi. A. Strosa definētais koncepts pagrieziena punkti būtībā ir tuvs N. Denzina formulētajām epifānijām naratīvos - momentiem, kuri pašos pamatos ietekmē cilvēku dzīvi, kas "strukturē biogrāfisko vai dzīves izpēti” (Denzin 1989: 70), un ir eksistenciālas krīzes. 
Analizēti D. Mandelbauma uzskati, pagrieziena punktus (turnings) attiecinot uz jebkuru periodu, kad indivīda dzīvē notiek būtiskas pārmaiņas, ieskaitot vēsturiskos pagrieziena punktus, kas gan precīzāk būtu saucami par vēsturiskajām zīmēm (historical markers), kā arī R. Tomsones lietotie termini kritiskie momenti pētījumos par pārrāvuma momentiem jauniešu dzīvē (Thomson et al. 2007) un R. Hamfrija (Humphrey) biogrāfiju pētījumos ieviestie koncepti karjeras lūzums un sociālā karjera (Humphrey 1993).

Promocijas darbā apskatīts krūts vēža gēna BRCA1 un BRCA2 pārmantojuma ietekme uz biogrāfiskā pārrāvuma veidošanos. Slimība un slimības paaugstināts risks kā biogrāfiskā pārrāvuma cēlonis raksturojami kā pārsvarā individuāli. Pārmantotā gēna ietekme izpaužas kā

1) indivīda paša slimība,

2) paaugstināts saslimšanas risks.

Abās situācijās biogrāfiskais pārrāvums ir kumulatīvs process, kurā ir ietverts ne tikai aktuālais notikums - indivīda slimība vai informācija par pārmantoto gēnu -, bet indivīdiem ir arī pieredze ar šīs slimības procesu un rezultātiem tuvu sociālo attiecību lokā, kurās tie ir saistīti ar genētisku tīklojumu, t.i., ar asinsradniecību.

Promocijas darbā otrs analizētais biogrāfiskais pārrāvums saistīts ar būtiskām pārmaiņām visās sabiedrības sistēmās, to skaitā arī kultūrā, kas ir visnoturīgākā, ar lielāko inerci, ir tradīcijās un kolektīvajā identitātē balstīta. Tāpēc sociālo pārmaiņu izraisītais biogrāfiskais pārrāvums analizēts saistībā ar kultūras traumu, kuras procesā notiek pārmaiņas makrosociālā līmenī, tieši vai netieši izpaužoties individuālā līmenī (Sztompka 2000).

Promocijas darba autore atsaucas uz Pjēra Burdjē izstrādātā jēedziena kapitāls interpretāciju. Promocijas darbā biogrāfiskā pārrāvuma problēmas analīzē viens no instrumentiem ir Burdjē habitus koncepts; ar habitus tiek saprasta dạ̧a no personiskās identitātes. Biogrāfiskais pārrāvums ienes pārmaiņas indivīda rīcībā esošā kapitāla lietošanas iespējās. Tā atklāšana un 
analīze ir īpaši svarīga strauju un radikālu sabiedrisko pārmaiṇu laikā, kad būtiski pieaug iespēja piekḷūt un pētīt habitus darbīibā.

Pētot un analizējot biogrāfiskā pārrāvuma pārvarēšanas iespējas, promocijas darbā secināts, ka tās ir paša indivīda veiktais biogrāfiskais darbs jeb naratīvā rekonstrukcija (Williams 2008) un dažāda veida sociālais atbalsts. Promocijas darba autore atsaucas uz A. Strosu, kas - tiesa gan, rakstot par smagu, ilgstošu slimību, - biogrāfisko darbu raksturo kā atgriešanos kaut vai aptuvenā iepriekšējā dzīvē vai arī tās būtiskā rekonstrukcijā. "Biogrāfiskais darbs kalpo aktora biogrāfijai, ietverot tās apskatu, uzturēšanu, salabošanu, pārveidošanu" (Corbin \& Strauss 1988: 70). Pēc promocijas darba autores domām, šāda atgriešanās dzīvē biogrāfiskā darba procesā attiecināma arī uz indivīdiem, kuri pārdzīvojuši sociālo pārmaiņu izraisītu biogrāfisko pārrāvumu.

Biogrāfiskā darba procesā, kas tiek veikts dažādu cēloṇu izraisītu biogrāfisko pārrāvumu gadījumos, indivīds mēǵina savienot savu iepriekšējo identitāti ar jauno identitāti, kas tapusi biogrāfiskā pārrāvuma procesā.

Biogrāfiskā pārrāvuma pārvarēšanā būtiski nozīmīgs ir dažāda veida sociālais atbalsts, kas veicina atgriešanos iepriekšèjā dzīvē vai indivīdu apmierinošu piemērošanos jaunajai situācijai. Sociālā atbalsta jēdziena lietojums un interpretācija kḷūst arvien vairāk starpdisciplināra, mēǵinot skatīt to kultūras kontekstā, pamatojot sociālā atbalsta saistību ar nozīmes struktūru, kas veido kultūru (Jacobson 1987). Rietumu industrializētajās kultūrās sociālais atbalsts tiek saistīts ar sociālo integrāciju, t.i., saprotot, ka sociālā iesaistǐšana vienmēr nozīme arī sociālo atbalstu. Sociālais atbalsts fokusējas uz indivīiu mijattiecībām, ietverot emocionālo, instrumentālo, informatīvo un izvērtējošo atbalstu. Socioloǵijā sociālā atbalsta resursus apskata kā atvasinātus no sociālā tīklojuma. Sociālā atbalsta uzdevums ir amortizēt, mazināt šokējošu, traumatisku notikumu negatīvo ietekmi uz indivīdu, palīdzot indivīdam sociāli adaptēties. Sociālā atbalsta pieejamība, iespēja izmantot dažādus tā veidus un resursus ir būtisks un nozīmīgs faktors ne tikai indivīda veselībā, bet arī 
labklājīibā kopumā. Sociālā atbalsta trūkums var veicināt sociālo atstumtību un sociālo izolāciju.

\subsection{Empīriskās analīzes metodoloǵija un datu avoti}

Biogrāfiskā pārrāvuma individuālo un sociālo aspektu socioloǵiskā izpētē promocijas darbā kā metodologija izmantota biogrāfiskā pieeja (2. nodaļa). Empīiskās analīzes metodoloǵija (3. nodaļa) izstrādāta, izmantojot Ketrinas Rīsmanes (Riessman), Ketijas Šārmezas (Charmaz), Roberta Millera (Miller) zinātnisko pētījumu pieredzi.

Empīiskā pētījuma metodolog̣ija ir induktīva, tā virzās no datu vākšanas empīriskajā pētījumā uz teorētisko analīzi un secinājumu izstrādi. Promocijas darbā līdzās empīriskajā dạ̦ā lietotajai induktīvajai metodologijai nozīmīga ir arī dedukcijas lietošana, jo promocijas darba procesā veikta teorētisko avotu un līdz šim izstrādāto pētījumu pieredzes izpēte. Izstrādājot biogrāfisko interviju vadlīnijas abām empīriskā pētījuma dalāàm, izmantoti Berija, Gidensa un citu teorētiskajā daḷa minēto autoru analītiskie jēdzieni.

Promocijas darbā biogrāfiskā pārrāvuma socioloǵiskajā analīzē izmantotas biogrāfiskās pieejas datu ieguves metodes: dzīves gājumu aptveroši naratīvi - dzīvesstāsti - un uz noteiktām tēmām fokusēti biogrāfiskie naratīvi.

Biogrāfiskās pieejas metodologiskie aspekti saistīti ar naratīva pētījuma veida izvēli. Biogrāfiskā pieeja tiek izmantota naratīva pētījumos kā personu dzīves pieredzes pierakstīšana un apkopošana, arī autobiogrāfisku materiālu izmantošana. Sociolog̣ijā personiskais naratīvs ietver garākas vai īsākas sarunas - paplašinātus stāstījumus par dzīvi, par konkrētiem dzīves posmiem vai problēmām. Šì pieeja virzīta uz to, lai izskaidrotu biogrāfiju, vēstures un sabiedrisko procesu mijiedarbību un to subjektīvo uztveri. Tajā pašā laikā jāuzsver, ka personiskā pieredze ietver sociālo pieredzi un ,,pētnieks fokusējas 
uz noteiktiem indivīdiem, noteiktās sociālajās vietās, noteiktos sociālajos laikos" (Riessman 2008: 11).

Promocijas darbā biogrāfiskā pārrāvuma analīzē izmantota neoreālistiskā pieeja (Roos 2003), kas respektē gan reālistiskās, gan naratīvās pieejas iezīmes, n̦emot vērā, ka dzīvesstāsts ir realitātes interpretācija. No reālistiskās pieejas pārṇemts uzskats, ka indivīdu viedokḷi kopumā atspoguḷo objektīvo realitāti, lai gan subjektīvā līmenī tie var būt daļēji nepatiesi. Jāatzīmē, ka reālistiskā pieeja izmanto pamatojuma teorijas principus: detalizētu un intensīvu datu analīzi, kurā frāzes, teikumi tiek komentēti, konstanti salīdzināti, dati tiek detalizēti kodēti pa tēmu grupām, savukārt promocijas darbā lietotā metodologija pārṇem naratīvajā pieejā izmantoto principu naratīva fragmentus apskatīt un analizēt $k \bar{a}$ vienības, nevis fragmentējot tematiskās kategorijās.

No naratīvās pieejas pārṇemta arī konteksta nozīmības un naratīva īpatnību un savdabības nozīmes atzīšana. Naratīvu analīzē ir daudz teorētisko pieeju un veidu: diskursa, semiotiskā, valodas, hermeneitiskā (Riessman 1993), kā arī tematiskā, strukturālā, dialoga jeb performances un vizuālā analīze (Riessman 2008). Promocijas darbā naratīvu izpētē lietots tematiskās analīzes princips, un tas kā naratīvā nozīmīgāko akcentē to, kas tiek stāstīts, nevis $k \bar{a}$ tiek stāstīts.

Raksturojot tematiskās naratīva analīzes pieejas atšķirības no pamatojuma teorijas, promocijas darba autore atsaucas uz Rīsmanes pieredzē balstītajiem teorētiskajiem secinājumiem:

1) par metožu atšķirību sākotnējo (prior) konceptu izvietojumā analīzes procesā. Ja pamatojuma teorijas pētījumā agrīnajā stadijā pastāv izvairīšanās no sākotnējā koncepta, tad naratīva tematiskajā analīzē tiek meklētas jaunas teorētiskās atziņas datu izpētes procesā, nenoliedzot teorētiskās nostādnes, pētījuma sākumā; 
2) būtiskākā iezīme naratīva tematiskajā analīzē - secības, stāsta un informācijas bagātības saglabāšana, ko ietver stāstam piemītošā secība;

3) atšķirībā no pamatojuma teorijas naratīva tematiskajā analīzē nozīmīga ir stāstīšanas vieta un laiks, tādējādi piešķirot stāstījumam zināmu vēsturiskumu;

4) pretstatā pamatojuma teorijā lietotajai kodēšanai vārds vārdā naratīvu tematiskā analīze ir centrēta uz gadījumu (case-centered) (Riessman 2008).

Promocijas darba pētījuma procesā teorētisko avotu izpēte integrēta ar empīrisko pētījumu gan laukdarba laikā, datu apstrādes procesā, gan noslēguma fāzē datu analīzē, pamatojoties uz intervijās iegūto empīrisko materiālu, formulējot nozīmīgākās analīzes tēmas.

Līdzās naratīvu analīzei konteksta raksturojumam izmantoti empīriskā pētījumā iesaistīto pētnieku veiktie interviju komentāri, personisko dokumentu un statistikas dati.

Promocijas darba empīiskajā pētījumā kā datu avoti hroniskas slimības vai tās paaugstināta riska kā biogrāfiskā pārrāvuma izpētē izmantoti dati, ko darba autore ieguvusi, strādājot pētījuma projektā „Jaunas starpdisciplināras zinātniskās grupas izveide krūts vēža izpētei, terapijas efektivitātes un pacienta dzīves kvalitātes uzlabošanai” (vienošanās Nr. 2009/0230/1DP/1.1.1.2.0/09/APIA/VIAA/070).

Minētā projekta ietvaros veiktais sociologiskais pētījums ietvēra kvantitatīvo aptauju ar krūts vēža slimniecēm pēc mastektomijas operācijas $(\mathrm{n}=300)$ un padzilinātās biogrāfiskās intervijas $(\mathrm{n}=15)$ ar sievietēm - krūts vēža pārmantotā gēna BRCAlun/vai BRCA2 nēsātājām. Promocijas darba empīriskajā pētījumā biogrāfiskā pārrāvuma izpētei un analīzei izmantotas padziļinātās biogrāfiskās intervijas, kurās ietverti jautājumi, kas attiecas uz saslimšanu ar krūts vēzi un saslimšanas paaugstinātiem riskiem. Padziļinātās intervijas un personiskie naratīvi, atklājot saslimšanas vai tās riska subjektīvo atspogulojumu un interpretāciju, parāda, kādā veidā sievietes uztver pārmantoto 
smago saslimšanu vai tās paaugstinātu risku un mēǵina sadzīvot ar to, ņemot vērā to ietekmi ne tikai uz viņu, bet arī uz turpmāko paaudžu dzīves gājumu.

Promocijas darba empīriskā pētījuma mērķa grupa ir personas ar pārmantoto krūts vēža $B R C A 1$ un/vai $B R C A 2$ gēnu. Pētījuma mērķa grupas izlase veidota no Rīgas Stradiña universitātes Onkoloǵijas institūtā esošās nacionālās datu bāzes, kas apkopo personu pārmantotā vēža vēsturi un $B R C A$ mutāciju ǵenētiskā testa rezultātus.

Projekta ietvaros veiktās kvantitatīvās aptaujas rezultāti un pieredze izmantoti kopējās problemātikas izpratnei un biogrāfisko interviju vadlīniju izstrādei.

Kardinālu sociālo pārmaiṇu izraisīta biogrāfiskā pārrāvuma izpētē dati no longitudinālā pētījuma, kas veikts LU FSI Nacionālās mutvārdu vēstures projektā. Vairāku gadu garumā, izmantojot biogrāfisko pieeju, veikts pētījums Māja, par informācijas avotu izmantojot dzīvesstāstu intervijas, interviju autoru personiskos dokumentus, kā arī pētnieku komentārus par interviju norisi un saturu. Konteksta raksturojumam izmantoti statistikas dati un informācija no pētījuma objektā veiktās kvantitatīvās aptaujas datu apkopojuma.

\subsection{Promocijas darba struktūra}

Promocijas darba struktūru veido ievads, sešas nodaļas, literatūras saraksts un trīs pielikumi.

Ievadā pamatota tēmas izvēle un raksturota tās novitāte, aktualitāte un pētījuma nozīmība sociolog̣ijā. Ievadā definēts pētījuma mērķis, pētījuma objekts, priekšmets un promocijas darbā izvirzītie uzdevumi.

Pirmajā nodaḷā analizēti biogrāfiskā pārrāvuma teorētiskie aspekti. Nodaļā analizēts biogrāfijas jēdziens, aprakstīts pētnieciskās problēmas izpētes teorētiskais pamatojums, sniegts biogrāfiskā pārrāvuma jēdziena skaidrojums, 
raksturota biogrāfiskā pārrāvuma vietu biogrāfijā kā dzīves gājuma subjektīvā interpretācijā, analizētas nozīmīgākās pieejas un koncepti kardinālu biogrāfisko pārmaiņu izpētē. Analizētas biogrāfiskā pārrāvuma būtiskākās pazīmes: identitātes lūzums jeb transformācija, kad tiek pārtraukta iepriekšējā identitāte un tās vietā veidojas cita identitāte, kas atbilst jaunajai situācijai; pārmaiņas sociālajās attiecībās un nepieciešamība piesaistìt resursus, tostarp ekspertus, kā arī pārmaiņas individuālo kapitālu un resursu pieejamībā un izmantošanā. Nodaļas noslēgumā teorētiski analizēta biogrāfiskā pārrāvuma veidošanās hroniskas slimības un kardinālu sociālo izmaiṇu perspektīvā.

Otrajā nodạ̦ā, lai pamatotu metodologijas - biogrāfiskās pieejas - izvēli promocijas darbā, veikta tās teorētiskā analīze, iztirzājot biogrāfiskās pieejas sociologijāa saturu un būtību, apskatot tās vēsturisko attīstību. Nodaļas turpinājumā uzmanība pievērsta naratīvu un dzīvesstāstu, kā arī biogrāfiskās izpētes datu analīzes pieeju analītiskam aprakstam.Teorētiskās nodaḷas noslēgumā apskatīti personisko datu ticamības aspekti.

Trešajā nodạ̦ā raksturota empīriskā pētījuma metodologiija. Tā kā promocijas darbā biogrāfiskais pārrāvums socioloǵiski analizēts, pamatojoties uz empīriskā pētījuma divām atsevišķām dạ̧ām, to metodologiskie aspekti raksturoti atsevišķās apakšnodal̦ās. Sniegts empīriskā pētījuma datu ieguves metožu, pētījuma norises un konteksta, respondentu atlases un demogrāfijas raksturojums un pamatojums, aprakstītas datu analīzes metodes un process.

Ceturtajā nodaḷā aprakstīti empīiskā pētījuma rezultāti, analizējot krūts vēža pārmantotā gēna nēsātāju biogrāfiskā pārrāvuma pieredzi. Atbilstoši naratīvu tematiskās analīzes pieejai uz noteiktām problēmām un tēmām fokusētajos naratīvos, kā arī dzīvesstāstu naratīvos analīzes galvenā uzmanība pievērsta tam, kas tiek stāstîts, nevis tam, kā tiek stāstîts, ņemot vērā arī stāstījumā ietverto notikumu kontekstu. Analizēti arī biogrāfiskā pārāvuma procesa individuālie un sociālie aspekti to mijiedarbībā, dažādus biogrāfiskāa 
pārrāvuma veidus un to pārvarēšanas iespējas aplūkojot atsevišķās apakšnodal̦ās.

Piektajā nodạ̦ā analizēti empīriskā pētījuma rezultāti par kardinālu sociālo pārmainuu ietekmi uz biogrāfiskā pārrāvuma procesu. Analizēta gadījuma pētījuma metodes izmantošana un vidutāja loma pētījuma rezultātu iegūšanā. Galvenā uzmanība nodaḷā fokusēta uz sociālo pārmaiṇu izraisītā biogrāfiskā pārrāvuma individuālo un sociālo aspektu analīzi un biogrāfiskā pārrāvuma pārvarēšanas veidiem - biogrāfisko darbu un sociālā atbalsta nozīmi un saņemšanas iespējām.

Nobeiguma un secinājumu nodaḷā apkopoti promocijas darba secinājumi, atbildot uz darba galvenajiem pētnieciskajiem jautājumiem par biogrāfiskajam pārrāvumam raksturīgajiem sociālajiem un individuālajiem aspektiem, dažādu cēloṇu izraisītu biogrāfisko pārrāvumu būtiskākajām paz̄imēm, kā arī rezumējot, kādi individuālie un sociālie faktori rada indivīdiem labvēlīgu situāciju un veicina veiksmīgu biogrāfiskā pārrāvuma pārvarēšanu.

Promocijas darbs aptver 193 lappuses. Promocijas darbā ir trīs pielikumi. Izmantotās literatūras sarakstā ietverti 240 avoti. 


\section{GALVENIE REZULTĀTI UN SECINĀJUMI}

Promocijas darba pētījumā veikta biogrāfiskā pārrāvuma individuālo un sociālo aspektu sociologiiska analīze. Pamatojoties uz pētījuma rezultātiem, izstrādāti secinājumi.

1. Biogrāfiskais pārrāvums ir plašs, individuālos un sociālos aspektus aptverošs jēdziens, kas raksturo procesu, ko ievada liktenīgais moments un kas ir analizējams dzīves gājuma kontekstā. Biogrāfisko pārrāvumu var izraisīt gan individuāli, personiska rakstura likten̄̄gie momenti, gan radikālas sociālās pārmaiņas. Tomēr jebkurš individuālu cēloṇu izraisīts biogrāfiskais pārrāvums ir saistīts ar sociālo mijiedarbību visā indivīda dzīves gājuma laikā.

2. Biogrāfiskais pārāvums ietver sevī gan individuālos, gan sociālos aspektus, kas atrodas mijiedarbībā un nav savstarpēji nošķirami. Sociālie aspekti attiecas uz indivīda dzīves gājumu sociālajā vidē - noteiktā laikā un telpā, biogrāfijā ietverot notikumu, pārmaiṇu pieredzes interpretāciju. Biogrāfiskā darba procesā individuālā pieredze tiek komunicēta citiem sabiedrības locekḷiem sociālo mijattiecību gaitā valodas formā, kas ir sociāls veidojums. Indivīda biogrāfija kā dzīves gājuma notikumu interpretācija ietver hronoloǵiskas laika dimensijas un dažāda līmeņa sociālo attiecību pieredzi, jo indivīds pārstāv noteiktu sociālo grupu un laiku. Biogrāfiskā pārrāvuma individuālie aspekti ir saistîti ar ikviena indivīda unikālo būtību un pieredzi, dzīves gājuma interpretāciju. Biogrāfiskā pārrāvuma procesā, ko ievada kritiskās situācijas vai liktenīgie momenti, izpaužas individuālā pieredze, indivīda rakstura īpašības un uztveres īpatnības, temperaments, individuālās identitātes aspekti.

3. Biogrāfiskais pārrāvums var tikt vispusīgi un dziļi izprasts, analizējot indivīda biogrāfiju visa dzīves gājuma laikā, kurā identificējas saistība starp sociālo vidi un indivīdu. Biogrāfiskā pārrāvuma izziṇa saistāma ar gimenes 
konteksta izpēti. Promocijas darbā analizēto biogrāfisko pārrāvumu izraisa indivīdu piederība noteiktai ǵimenei. Tā ir piederība gimenei ar noteiktu genētisko kodu, kas ir pamatā paaugstinātam slimības riskam, un piederība ǵimenei, kas pārstāv noteiktu sociālo grupu, kas kardinālu sociālo pārmaiṇu situācijā ir tikusi pakḷauta represijām. Sociālo pārmaiņu izraisīta biogrāfiskā pārrāvuma atspoguḷojums parāda indivīda pieredzes saistību ar lielajām sociālajām transformācijām, vēsturiskajām pārmaiņām.

4. Biogrāfiskais pārrāvums ir kumulatīvs process ar traumatisku raksturu, tā būtiskākās pazīmes ir identitātes transformācija, sociālo attiecību pārmaiņas, ekspertu un resursu piesaistes nepieciešamība pārrāvuma pārvarēšanai.

5. Dažādu cēloṇu izraisītiem biogrāfiskajiem pārrāvumiem raksturīgās kopīgas būtiskās pazīmes var izpausties atšķirīgi. Promocijas darbā analizētā genētiskā mantojuma gadījumos, kas ir slimības paaugstināta riska faktors, kā arī - īpaši slimības gadījumos - uzsvērta ķermeniskās identitātes un tās apdraudētības nozīme individuālās identitātes nepārtrauktībā. Indivīdiem ar paaugstinātu saslimšanas risku raksturīga divu veidu attieksme pret gēna diagnosticēšanu: sagatavošanās un noliegums. Noliegums kā negatīvo seku un negatīvās domāšanas nepieļaušana, bailes par ǵenētiskā testa pozitīvu rezultātu ir emocionāli saudzējošs, identitāti sargājošs, tomēr ietver nepietiekamu slimības risku novērtējumu. Ģenētiskā pārmantojuma noskaidrošanas pozitīvie aspekti ir indivīda pašvērtējuma paaugstināšanās identitātes transformācijas procesā, pastiprināta uzmanība veselības uzturēšanas pasākumiem slimības risku samazināšanai sev un tuviniekiem. Veselības aprūpes speciālistiem vajadzētu uzsvērt šos pozitīvos aspektus un komunicēt tos indivīdiem ar paaugstinātu saslimšanas risku. Radikālu sociālo pārmaiņu izraisīts biogrāfiskais pārrāvums norisinās kultūras traumas kontekstā, jo kultūra ir sfēra ar lielu inerci, pastāvību, tradīcijām, kolektīvajā atmiņā nostiprinātām vērtībām, sabiedrības identitātes nepārtrauktību, tajā ietverta indivīda kultūras identitāte 
ar vērtību, sociālo attiecību nozīmes apzināšanos. Radikālām sociālajām pārmaiņām ir īpaši traumējošas sekas, makrosabiedriskām traumatiskām izmaiņām ietekmējot sabiedrību makrolīmen̄̄, ietekmējot grupas funkcionēšanu mikromērogā un katra indivīda dzīves gājumu. Sociālo pārmainu radītā identitātes transformācija saistīta ar sociālās identitātes dažādu aspektu piespiedu maiņu savas eksistences saglabāšanai, kā arī identitātes atšķirīgu reprezentāciju privātajā un publiskajā telpā.

6. Analizējot sociālo attiecību pārmaiņas biogrāfiskā pārrāvuma procesā, izriet secinājums, ka sociālo attiecību pārmainas slimības vai tās paaugstināta riska situācijāâ, attiecību dalībnieku iesaistīšanās sociālajā atbalstā ietekmē slimības skartā vai apdraudētā indivīda pašvērtējumu un vērtību sistēmu. Pētījuma rezultātu analīze apstiprina tuvu atbalstošu attiecību, īpaši partnerattiecību, būtisko nozīmi individuālās labsajūtas, identitātes saglabāšanas un biogrāfiskā pārrāvuma pārvarēšanā. Kardinālu sociālo pārmaiṇu izraisīta biogrāfiskā pārrāvuma situācijā gan tuvākas, gan tālākas sociālās attiecības tiek vardarbīgi pārrautas. Šim pārrāvumam sekojošo sociālo attiecību veidošana un pastāvēšana saistīta ar eksistences nodrošināšanu un izdzīvošanas stratēgiju.

7. Biogrāfiskā pārrāvuma pārvarēšana var tikt īstenota, indivīdam saņemot sociālo atbalstu un veicot biogrāfisko darbu, kas ir indivīda interpretatīvs pārskats par savu dzīves gājumu individuālo un sociālo aspektu mijiedarbībā.

8. Dažādu cēloṇu izraisīta biogrāfiskā pārrāvuma gadījumos atšķirīgs ir uzmanības fokuss uz galvenajām tēmām un biogrāfiskā pārrāvuma skaidrojumu biogrāfiskā darba procesā. Slimības vai tās paaugstināta apdraudējuma gadījumos biogrāfiskā darba procesā tiek meklēts un analizēts genētiskā mantojuma un slimības pamatojums un cēloṇi individuālajā un tuvinieku pieredzē, personiskajā identitātē. Slimības izcelsme un tās cēloņi tiek skaidroti neviennozīmīgi, slimības izcelsmi pamatojot ne tikai ar biomedicīniskiem, bet 
arī ar citiem faktoriem - ārējiem jeb vides, sociālajiem, psihiskajiem, mistificētajiem. Kardinālu sociālo pārmainu gadījumā notikumu pamatojums netiek meklēts, respondentēm ir viennozīmīgi skaidrs tā cēlonis - tā ir varas realizētā vardarbība un netaisnība. Biogrāfiskajā darbā respondentes izstāsta par savām un savu tuvinieku ciešanām, interpretē savas izdzīvošanas stratēgijas un iespējas.

9. Atšķirīgi ir biogrāfiskā darba laika aspekti dažādu cēloņu izraisītu biogrāfisko pārrāvumu gadījumos. Slimības vai tās paaugstināta riska situācijā biogrāfiskais darbs tiek veikts vienlaikus ar slimības diagnozes noteikšanu, slimības ārstēšanu. Promocijas darbā analizētā sociālo pārmaiṇu izraisīta biogrāfiskā pārrāvuma situācijā biogrāfiskais darbs tiek veikts ar vairāku gadu desmitu nobīdi laikā - jau pēc politiskās sistēmas maiñas. Individuālais biogrāfiskais darbs ir ilgstoši noklusētās kolektīvās atmiņas daļa, kas ieguvusi iespēju izpausties. Tā ir daḷa no visas tautas kolektīvajām atmiņām kultūras traumas kontekstā.

10. Atšķiras privātās un publiskās telpas attiecības promocijas darbā analizēto biogrāfisko pārrāvumu situācijās. Slimības un tās paaugstināta riska situācijā indivīda problēmas tiek risinātas gan privātajā, gan publiskajā telpā, piesaistot konsultantus, speciālistus, izmantojot iespējas piedalīties atbalsta grupās, ieskaitot dažāda veida sociālo tīklu izmantošanu. Sociālo pārmaiņu izraisīta biogrāfiskā pārrāvuma situācijā privātā un publiskā telpa ir stingri nodalītas viena no otras, atšķiroties arī identitātes pozicionēšanai privātajā telpā un publiskajā telpā.

11. Biogrāfiskais darbs, kas tiek veikts dažādu cēloṇu izraisītu biogrāfisko pārrāvumu gadījumos, ietver dziedināšanas funkciju, mēǵinot savienot iepriekšējo identitāti ar jauno identitāti, kas main̄̄jusies biogrāfiskā pārrāvuma procesā. Biogrāfiskais darbs ietver indivīda un sociālās vides mijiedarbības interpretāciju, apliecinot, ka individuālie un sociālie aspekti biogrāfiskajā pārrāvumā nav savstarpēji nošksirami. 
12. Biogrāfiskais pārrāvums nosaka ekspertu un resursu piesaistes nepieciešamību, tajā pašā laikā tas ietver arī individuālo kapitālu pieejamības un izmantošanas iespēju samazināšanos vai zaudējumu. Biogrāfiskā pārrāvuma pārvarēšanai būtiski nozīmīgs ir sociālais atbalsts dažādās formās, kas veicina atgriešanos iepriekšêjā dzīvē vai indivīdu apmierinošu piemērošanos jaunajai situācijai. Biogrāfisko pārrāvumu gadījumos nozīmīgāko sociālo atbalstu sniedz tuvāko sociālo attiecību dalībnieki. Sociālais atbalsts pozitīvi ietekmē identitātes saglabāšanu vai rekonstrukciju, individuālo labsajūtu, kā arī mazina biogrāfiskā pārrāvuma traumatisko raksturu. Sociālais atbalsts ir arī nozīmīgs faktors indivīda marginalizācijas risku novēršanai.

13. Dažādu cēloṇu izraisīta biogrāfiskā pārrāvuma gadījumos atšķiras sociālā atbalsta saturs, nepieciešamība un saņemšanas iespējas. Promocijas darbā apskatītā sociālo pārmaiṇu izraisīta biogrāfiskā pārrāvuma situācijās sociālais atbalsts pieejams ierobežotā apjomā, un tas tiek sniegts tuvākajā sociālo attiecību lokā. Sociālā atbalsta meklējumi publiskā sfērā, kā arī biogrāfiskais darbs ārpus tuvākajām sociālajām attiecībām ir eksistences apdraudējums.

14. Slimības vai tās paaugstināta riska gadījumā iespējama problēmas komunicēšana un dažādu veidu sociālā atbalsta meklējumi plašā mērogā. Pastāvot profesionālu ekspertu - veselības aprūpes speciālistu - sniegtā sociālā atbalsta (tāda, kas kompleksi aptvertu informatīvos, izvērtēšanas un emocionālos aspektus) deficītam, indivīdi meklē mistificētus skaidrojumus un atbalstu, taču tas var radīt neadekvāta sociālā atbalsta risku, kas neveicina veselības uzlabošanos. Stāstījumos identificējas nepieciešamība pēc ekspertiem, kas varētu sniegt profesionālu un kompleksu sociālo atbalstu.

15. Slimības izraisīta biogrāfiskā pārrāvuma gadījumā, indivīdiem būtiskāko sociālo atbalstu saņemot no tuvākajiem sociālo attiecību dalībniekiem, pārsvarā - no ǵimenes, mainās gimenes locekḷu sociālās lomas, pieaug viņu emocionālā spriedze. Hroniska smaga slimība var radīt biogrāfisko 
pārrāvumu ne tikai pašam indivīdam, bet arī sociālo attiecību tuvākajām personām. Tādējādi arī gimenei ir nepieciešams sociālais atbalsts. Šajā jomā līdz šim veikts maz pētījumu. Lai indivīds veiksmīgi sadzīvotu ar paaugstinātu slimības risku vai slimību, respondentu stratēgijas ietver pārliecību, ka veselīgs dzīvesveids, stresa samazināšana, regulāras veselības pārbaudes novērsīs saslimšanas risku un palielinās dzīvildzi. 


\section{PROMOCIJAS DARBA APROBĀCIJA}

\subsection{Promocijas darba autores zinātniskās publikācijas par promocijas darba tēmu}

1. M. Pranka, A. Dzervite, R. Rungule, T. Lace, E. Miklasevics, J. Gardovskis (2014). Assessment of life quality factors by breast cancer patients. SHS Web conferences, Vol. 10. Published online: 9 September 2014. DOI: http://dx.doi.org/10.1051/shsconf/20141000034; HS Web of Conferences, Vol. $10,2014,4^{\text {th }}$ International Interdisciplinary Scientific Conference "Society, Health, Welfare".

2. M. Pranka (2013). We did not tell anything to the strangers. Communication between private and Soviet public space. In: Oral History:Dialogue with Society/Mutvārdu vēsture: Dialogs ar sabiedrību. Red. I. Garda-Rozenberga. Rīga: LU FSI; Latvijas Mutvārdu vēstures pētnieku asociācija "Dzīvesstāsts", 188.-194. lpp.

3. M. Pranka (2012). Biogrāfiskais pārrāvums kā pieredze dzīves gājumā. Nodaļa kolektīvajā monogrāfijā Dzīvesstāsts un pašapzinga. Mutvārdu vēsture Latvijā. Rīga: LU FSI; Latvijas Mutvārdu vēstures pētnieku asociācija "Dzīvesstāsts", 58.-71. lpp.

4. Dzervite, M. Pranka, T. Lāce, R. Rungule, J. Gardovskis, E. Miklasevics (2013). Initial findings of breast cancer risk factors from a survey conducted at Pauls Stradins Clinical University Hospital. Acta Chirurgica Latviensis (RSU), 13, pp. 34-37.

5. Dzervite, M. Pranka, A. Irmejs, J. Gardovskis, E. Miklasevics (2012). Overcoming potential suffering: Interpreting the diagnosis of hereditary ovarian and breast cancer at the Riga Stradins University Oncology Institute. Pieejams: http://www.inter-disciplinary.net/probing-the-boundaries/wp- 
content/uploads/2012/10/dzervitesufpaper.pdf; sk. arī konferences mājaslapā: http://www.inter-disciplinary.net/probing-the-boundaries/making-senseof/suffering/project-archives/conference-programme-papers-andabstracts/session-2-adaptations/

6. M. Pranka (2011). Biogrāfiskās pieejas iespējas migrācijas izpētē. No: Kultūras identitātes dimensijas. Zin. red. S. Krūmiņa-Koṇkova. Rīga: LU FSI, 169. -187 .

7. Pranka (2010). Individuālās biogrāfijas kā sociālās izziṇas resurss laikmeta procesu pētniecībā. No: RSU Zinātniskie raksti 2010. Atb. red. A. Lapsa. Rīga: RSU, 129.-136. lpp.

8. M. Pranka (2010). Migration as loss of home". In: Oral History: Migration and Local Identity: Online proceedings of papers presented at the Conference at the University of Latvia in Riga, June 27-29, 2008, pp. 222-231.

9. M. Pranka (2010). Значение биографических исследований в период социально-экономического кризиса. In: Partnerstwo i wspolpraca a kryzys gospodarczo-spoleczny w Europie Šrokowej i Wschodniej, t. 2, pod redakcja S. Prtyckiego. Lublin: Katolicki Uniwersitet Lubelski Jana Pawla II, Wydawnictwo KUL, s. 785-791.

10. M. Pranka (2010). Methodological approach aspects in researching social processes and situation of children in risk. In: Collection of Scientific Papers 2009. Rīga: RSU, pp. 216-219

11. M. Pranka (2009). Biographical approach in researh of social processes in a case study. In: Proceedings of the International Conference "Risk Society: Challenges for the 21st Century", Athens, 2009. Sañemts apstiprinājums par publicēšanu.

12. M. Pranka (2009). Migratsioon versus kodu: vaateid ühele uurimisprojektile. In: Maetagused, 43. Red. Koiva and A. Kuperjanov. Tartu, 2009, 1k. 85-104 
13. M. Pranka (2008). Biogrāfiskā pieeja sociālo procesu vērtējumā. No: Letonika. Otrais kongress. Nacionālā mutvārdu vēsture. Reliǵiskās idejas Latvijā, 2. grām. Rīga, FSI, 2008, 127.-135. lpp.

14. M. Pranka. Identitāte reǵionālās attīstības kontekstā. No: Dzīvesstāsti: vēsture, kultūra, sabiedrība. Rīga: LU FSI; NMV, 2007, 350.354. 1pp.

\subsection{Referāti un ziṇojumi par promocijas darba tēmu konferencēs}

\section{un kongresos}

1. M. Pranka, E. Miklaševičs, L. Līvmane (2014). “Attieksme pret krūts un olnīcu vēža profilaktiskajām apskatēm un to ietekmējošie faktori. Sociologiiskās aptaujas rezultāti”. RSU Zinātniskā konference, 10.11.2014. Rīga.

2. M. Pranka (2013). "Biogrāfiskais lūzums: kultūras trauma dzīvesstāstos". Letonikas 5. kongress, 28.-30. 10.2013. Rīga.

3. M. Pranka, A. Dzērvīte, R. Rungule, J. Gardovskis, E. Miklaševičs (2013). "Risk of hereditary dreast cancer as biographical disruption: . Eiropas Sociologu asociācijas (ESA) 13. zinātniskā konference "Crisis, Critique and Change", 28.-31.08.2013. Turīnas Universitāte, Itālija.

4. M. Pranka (2013). "Experience of biographical disruption. Consequences and risks". Eiropas Sociologu asociācijas (ESA) 13. zinātniskāa konference "Crisis, Critique and Change" 28.-31.08.2013. Turīnas Universitāte, Itālija.

5. M. Pranka (2012). "Slimība kā dz̄ives pagrieziena punkts. Subjektīvais vērtējums" (Illness as life's turning point. subjective evaluation). Ziemel̦valstu Sociolog̣ijas asociācijas 26. konference "Trust and Social Change", 2012, augusts. Reikjavīka, Īslande. 
6. M. Pranka (2012). "Biogrāfiskā pieeja daudzdisciplinārā pētījumā”" (Biographical approach in multidisciplinary research). Starptautiska konference "Humanities and Contemporary World", 2012, jūnijs. Podgorica, Melnkalne.

7. M. Pranka (2012). "Biogrāfiskais pārrāvums kā pieredze dzīves gājumā”. 15. starptautiskā zinātniskā konference "Sabiedrība un kultūra: Main̄̄gais un nemain̄̄gais cikliskumā”, 2012, maijs. Liepāja.

8. M. Pranka (2012). "Biogrāfiskais lūzums un tā komunikācija padomju telpā”. Starptautiskā zinātniskā konference "Mutvārdu vēsture: Dialogs ar sabiedrību”, 2012, marts. Rīga.

9. M. Pranka (2011). "Identitāte migrācijas krustcelēs" (Identity in the Crossroads of Migration). Eiropas Sociologu asociācijas 10. konference "Sociālās attiecības trauksmainā laikā" ("Social Relations in Turbulent Times”), 2011, septembris. Ženēva, Šveice.

10. M. Pranka, A. Dzērvīte, T. Lāce, R. Rungule, A. Irmejs (2011). "Sociological dimensions in breast cancer multidisciplinary research". Eiropas Sociologu asociācijas (ESA) 10. konference "Sociālās attiecības trauksmainā laikā" ("Social Relations in Turbulent Times"), 2011, septembris. Ženēva, Šveice.

11. M. Pranka (2011). "Migrācijas procesi un sieviešu dzīves trajektorijas". 14. starptautiskā zinātniskā konference "Sabiedrība un kultūra: Robežas un jauni apvāršņi”, 2011, maijs. Liepāja.

12. M. Pranka (2010). "Refleksijas par biogrāfiskiem pētījumiem, pētot sociālos un telpas procesus Latvijā". (Reflection on the biographical study in researching social and spatial processes in Latvia). Starptautiska zinātniskā konference "Applied Biographical Research / Anwendungsbezüge der Biographieforschung", 2010, septembris. Nirnberga, Vācija.

13. M. Pranka (2010). "Biogrāfisko pētījumu nozīmība sociālekonomiskās krīzes periodā" (The relevance of biographical researches in the period of socio-economical crisis). Starptautiska zinātniskā konference 
"Partnership and Cooperation in the Period of Socio-Economical Crisis in Central and Eastern European Countries", 2010, maijs. Nalenčevo, Polija.

14. M. Pranka (2010). "Biogrāfiskā pieeja sociologijāa - teorijas un prakses paradokss”. 13. starptautiskā zinātniskā konference „Sabiedrība un kultūra: Haoss un harmonija”, 2010, aprīlis. Liepāja.

15. M. Pranka (2010). "Dzīves stāstu lietojuma sociālo procesu izpētē metodologiskie aspekti" (Methodological aspects of use life history research for investigation social processes). Starptautiska zinātniskā konference "Mutvārdu vēsture un laukdarbs. Materiālu lietošana un interpretācija”, 2010, decembris. Helsinki, Somija.

16. M. Pranka (2011). "Mēs svešiem neko nestāstījām. Par identitāti privātajā un padomju publiskajā telpā”. Apvienotais III Pasaules latviešu zinātnieku kongress un IV Letonikas kongress, 2011, oktobris. Rīga.

17. M. Pranka (2010). "Biogrāfisko pētījumu izmantojums socioloǵiskā izpētēe”. Rīgas Stradiṇa universitātes Zinātniskā konference, 2010. Rīga.

18. M. Pranka (2009). "Biogrāfiskā pieeja sociālo procesu izpētē". Starptautiska zinātniskā konference "Risk Society: Challenges for the $21^{\text {st }}$ Century”, 2000, novembris. Atēnas, Grieķija.

19. M. Pranka (2009). "No atmiņām uz sociālo procesu izziṇu. Gadījuma analīze“. Starptautiska zinātniskā konference "Lithuanian Eurointegration, National Identity, and Collective Historical Memory”, 2009, novembris. Viļ̣na, Lietuva.

20. M. Pranka (2009). "Dzīvesstāsti kā izziṇas avots un pētījuma metode". Starptautiska konference "Sociālā darba perspektīvas un iespējas mūsdienīgā Eiropā̄”, 2009, marts. Rīga.

21. M. Pranka (2008). "Migrācijas procesu analīze biogrāfiskā pētījumā". Starptautiska starpdisciplinārā konference "Society, Health, Welfare”, 2008, novembris. Rīga. 
22. M. Pranka (2008). "Migration versus home". Starptautiska konference "Oral History: Migration and Local Identities" 2008, jūnijs. Rīga.

23. M. Pranka (2007). "Biogrāfiskā pieeja sociālo procesu vērtējumā". Letonikas kongress. Rīga.

24. M. Pranka (2007). "Mūsu dzīves telpa. Biogrāfiskās metodes iespējas vides pētniecībā”. Eiropas Sociologu asociācijas 8. konference, 2007, septembris. Glāzgova, Lielbritānija.

\subsection{Publicētās tēzes zinātnisko konferenču tēžu krājumos un interneta resursos}

1. M. Pranka, E. Miklaševičs, L. Līvmane. Attieksme pret krūts un olnīcu vēža profilaktiskajām apskatēm un to ietekmējošie faktori. Socioloğiskās aptaujas rezultāti. Tēzes. RSU 2014. g. zinātniskā konference. Rīga, 2014, 276. 1pp.

2. M. Pranka, A. Dzērvīte, R. Rungule, J. Gardovskis, E. Miklaševičs. Risk of hereditary breast cancer as biographical disruption. Tēzes referātam Eiropas Sociologu asociācijas (ESA) 13. zinātniskajā konferencē „Crisis, Critique and Change”, 28.-31.08.2013. Turīnas Universitātē, Itālijā.

3. M. Pranka. Experience of biographical disruption. Consequences and risks. Tēzes referātam Eiropas Sociologu asociācijas (ESA) 13. zinātniskajā konferencē "Crisis, Critique and Change", 28.-31.08.2013. Turīnas Universitātē, Itālijā.

4. M. Pranka, A. Dzērvīte, J. Gardovskis, E. Miklaševičs "Slimība kā dzīves pagrieziena punkts. Subjektīvais vērtējums" (Illness as life's turning point. Subjective evaluation). Tēzes referātam Ziemel̦valstu Socioloǵijas asociācijas 26. konferencē "Trust and Social Change", 2012, augusts. Reikjavīka, Īslande. 
5. R. Rungule, M. Pranka, T. Lāce, A. Dzērvīte, E. Miklaševičs. "Biographical experience of women with cancer". Tēzes referātam Starptautiskās sociologu asociācijas Pasaules sociologu 2. forumā 1.4.08.2012.

Buenosairesa, Argentīna; https://isaconf.confex.com/isaconf/forum2012/webprogram/Paper27445.html

6. M. Pranka. "Septiņdesmito gadu jauniešu socioloǵiskā pieredze". Tēzes referātam starptautiskā konferencē "Jaunatne Latvijā, Eiropā, pasaulē: iespējas un riski”, 2012, jūnijs. Rīga.

7. M. Pranka, "Biographical break and its communication in the Soviet space". Tēzes referātam starptautiskā konferencē "Mutvārdu vēsture: dialogs ar sabiedrību" (Oral History: Dialog with Society), 2012, marts. Rīga.

8. M. Pranka, A. Dzērvīte, J. Gardovskis, E. Miklaševičs. "Socioloğisko rādītāju atšķirības par 65 gadiem jaunākām un vecākām krūts vēža slimniecēm”. Tēzes. RSU 2012. g. zinātniskā konference. Rīga, 2012.

9. M. Pranka, A. Dzērvīte, T. Lāce, R. Rungule, A. Irmejs. "Sociological dimensions in breast cancer multidisciplinary research". Tēzes referātam Eiropas Sociologu asociācijas (ESA) 10. konferencē "Sociālās attiecības trauksmainā laikā" (European Sociological Association, 10th conference "Social Relations in Turbulent Times"). 2011, septembris. Ženēva.

10. M. Pranka. „Identity in the Crossroads of Migration”. Tēzes referātam Eiropas Sociologu asociācijas (ESA) 10. konferencē "Sociālās attiecības trauksmainā laikā" (European Sociological Association, 10th conference "Social Relations in Turbulent Times"). 2011, septembris. Ženēva.

11. M. Pranka, A. Dzērvīte, T. Lāce, R. Rungule, E. Miklaševičs, J. Gardovskis. "Dz̄ives kvalitātes mērījumi krūts vēža slimniecēm P. Stradiṇa Klīniskajā universitātes slimnīcā”. Tēzes. RSU 2011. g. zinātniskā konference. Rīga, 2011. 
12. M. Pranka, A. Dzērvīte, T. Lāce, R. Rungule, E. Miklaševičs, J. Gardovskis. "Sociologisko aspektu izpēte krūts vēža pētìjumā”. Tēzes. RSU 2011.g. zinātniskā konference. Rīga, 2011.

13. M. Pranka. "Biographical knowledge as professional competence in researching society”. Tēzes starptautiskā konferencē „Rehabilitation Days”. Rīga, 2010.

14. A. Dzērvīte, M. Pranka. "Dzīves kvalitātes mērījumu izmantošana pētījumā par krūts vēža klīnisko, morfoloǵisko un molekulāro īpatnību korelāciju izpēti dzīves kvalitātes uzlabošanai”. Tēzes. RSU 2010. g. zinātniskā konference, 2010, marts. Rīga.

15. M. Pranka. "Biogrāfisko pētījumu izmantojums socioloǵiskā izpētē". Tēzes. RSU 2010. g. zinātniskā konference, 2010, marts. Rīga.

16. M. Pranka. "From memories to inquiring the social processes: case study analysis". Tēzes starptautiskā konferencē "Lithuanian Euro-Integration, National Identity, and Collective Historical Memory”, 2009, novembris. Viḷna.

17. M. Pranka. "Migration: the opposite of home: a case study", starptautiska konference "Mutvārdu vēsture: migrācija un lokālā identitāte" („Oral History: Migration and Local Identity”), 2008, jūnijs. Rīga. 


\section{LITERATŪRA}

1. Boldt, T. D. (2012). Migration biography and ethnic identity: on the discontinuity of biographical experince and how tuning points affect the ethnicisation of identity. In: Hackstaff, K., Kupferberg, F., and Negroni, C. (eds.). Biography and Turning Points in Europa and America. University of Bristol, UK: The Policy Press, pp. 93-124.

2. Bourdieu, P. (1986). The forms of capital. In: Richardson, J. G. (ed.). Handbook of Theory and Research for the Sociology of Education. New York: Greenwood Press, pp. 241-258.

3. Bury, M. (1982) Chronic illness as biographical disruption. Sociology of Health and Illness, Vol. 4, No. 2, pp. 167-182.

4. Chamberlayne, P., Bornat, J. and Wengraf, T. (eds.). (2000). The Turn to Biographical Methods in Social Science: Comparative Issues and Examples. London: Routledge.

5. Charmaz, K. (1995). The body, identity, and self: Adapting to impairment. The Sociological Quarterly, Vol. 36, pp. 657-680.

6. Charmaz, K. (2002). Stories and silences: disclosures and self in chronic illness. Qualitative Inquiry, Vol. 8, No 3. pp. 302-327.

7. Corbin, J. M. and Strauss, A. L. (1987). Accomplishments of chronic illness: Changes in body, self, biography, and biographical time. In: Roth, J. A. and Conrad, P. (eds.). Research in the Sociology of Health Care, vol. 6: The Experience and Management of Chronic Illness. Greenwich: J.A.I. Press, pp. 249-281.

8. Denzin, N. K. (1990). Interpretive Interactionism. Newbury Park, CA: Sage Publications.

9. Giddens, A. (1979). Central Problems in Social Theory. London: Macmillan; Berkeley: University of California Press.

10. Giddens, A. (1991a). Modernity and Self-identity: Self and Society in the Late Modern Age. Stanford: Stanford University Press.

11. Glaser, B. and Strauss, A. L. (1968). Time for Dying. Chicago: Aldine.

12. Heinz, W.R. and Krüger, H. (2001). Life course: innovations and challenges for social research. Current Sociology, Vol. 49, No. 2, pp. 29-45.

13. Lūse, A. (2007). Patības balss un cēloņsakarību atbalss sižetos par krīzes pieredzi. No: Dzīvesstāsti: vēsture, kultūra, sabiedrība. Rīga: LU FSI NMV, 269.-283. lpp.

14. Mathieson, C. M. and Stam, H. J. (1995). Renegotiating identity: cancer narratives. Sociology of Health \& Illness, Vol. 17, No. 3, pp. 282-306.

15. Mežinska, S. (2010). Hroniskas slimības subjektīvā pieredze un pensijas vecuma cilvēku dzīves kvalitāte. Promocijas darbs socioloǵijas nozarē. Rīga: RSU. SAGE.

16. Miller, R.L. (2000) Researching Life Stories and Family Histories. London:

17. Pranka, M. (2009). Migratsioon versus kodu: vaateid ühele uurimisprojektile. Mäetagused: An electronic journal of folklore, Vol. 43, pp. 85-104. 
18. Pranka, M. (2012). "Biogrāfiskais pārrāvums kā pieredze dzīves gājumā”, nodaļa kolektīvajā monogrāfijā Mutvārdu vēsture: dzīvesstāsts un pašapziņa. Red. I. Garda-Rozenberga. Rīga: LU FSI, 58.-71. lpp.

19. Riessman, C. K. (2002). Illness Narratives: Positioned Identities: invited annual lecture. Cardiff, Wales: Health Communication Research Centre, Cardiff University.

20. Riessman, C. K., (2008) Narrative Methods for the Human Sciences. SAGE Publications.

21. Roos, J. P. (2003). Context, authentity, referentiality, reflexivity: back to basics of autobiography. In: Humphrey, R., Miller, R., Zdravomyslova, E. (eds.). Biographical Research in Eastern Europe: Altered Live and Broken Biographies. London: Ahgate, pp. 27-38.

22. Skultāne, V. (2002). Naratīvs un slimība. No: Lūse, A. (sast.). Cilvēks. Dzīve. Stāstījums. Rīga: Latvijas Antropologu biedrība, 13.-22. lpp.

23. Skultāne, V. (2001). Liktenis un biogrāfiju veidošana. No: Zirnīte, M. (sast.). Spogulis: Latvijas mutvārdu vēsture. Rīga: LU FSI, NMV, 46.-70. lpp.

24. Skultans, V. (1998). The Testimony of Lives: Narrative and Memory in Post-Soviet Latvia. London; New York: Routledge.

25. Skultans, V. (1999). Narratives of the body and history: illness in judgment on the Soviet past. Sociology of Health and Illness, Vol. 21, No. 3, pp. 310-328.

26. Skultans, V.S. (2001). A historical disorder: neurasthenia and the testimony of lives. In: Bhurga, D. and Littlewood, R. (eds.). Colonialism and Psychiatry. Delhi: Oxford University Press, pp. 244-264.

27. Skultans, V. (2002). Editorial: Narrative, illness and the body. Anthropology and Medicine, Vol. 7, No. 1, pp. 5-13.

28. Sztompka, P. (2000). Cultural Trauma. The other face of social change. European Journal of Social Theory, Vol. 3, No. 4, pp. 449-466. 